[Barrington, J. (1998). Central and Local Control in Education. New Zealand Annual Review of Education, 7, 79-93]

\section{Central and Local Control in Education}

\section{JOHN BARRINGTON}

\section{Abstract:}

The question of the extent to which education should be centrally or locally controlled and administered has been a hardy perennial in New Zealand. It was being vigorously debated even prior to the passing of the 1877 Education Act, which established the national system and, far from lessening in importance, became central to the 1989 education reforms. This paper begins by briefly examining the situation prior to Tomorrow's Schools and then explores trends and issues until the present day, concluding with a discussion of the Coalition Agreement on Education.

At what point then, between extreme centralisation and extreme localism, between extreme expert and extremelay control, should we hope to find the conditions that will ensure a system of education appropriate to the nation's needs. (James Hight in Webb, 1937, p. vi.)

Like the Duke of York's troops, the Ministry has been marched up to the top of the hill and now appears to be - if not on their way back down again - perhaps neither up nor down. (State Services Commission, 1996, p. 83)

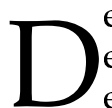

bate over the relative merits of central versus local control in education has a long-standing history, with philosophers and educators ever since Plato arguing that neither form of control is necessarily a bad thing in itself. At best both have some potentially favourable characteristics; at worst each also has the potential to support questionable education practice.

Some of the advantages most frequently put forward in favour of decentralization include: Participation: there is more democracy for participants in a decentralised structure; Legitimacy: greater consensus

\section{John Barrington}

is possible when decisions are made on a participatory basis; Proximity: real needs at the local level are more likely to be responded to and addressed quickly in a decentralised system; Creativity and innovation: participation facilitates individual creative processes; Integration: the internal coherence of the local organization is facilitated; Efficiency: costs and inefficiencies in central offices are reduced (see International Encyclopaedia of Education (1985) and Weiler (1990) for a fuller account).

Arguments for centralization include: the need to ensure fairness for all students in terms of equity of provision; the need to maintain consistent standards across the whole country in such areas as curriculum and examinations; the need to ensure that schools are not "captured" by over-zealous parents; and the desirability of obtaining benefits from economies of scale.

\section{New Zealand Prior to 1989}

In New Zealand the merits of central versus local control were fiercely disputed between centralists and provincialists at least until the turn of the present century. The Department of Education, established by the 1877 Education Act, symbolized an attempt at compromise between the warring factions, initially being kept deliberately minuscule in size with only limited powers. For several decades, the main authority for policy making and for most important educational administration lay with the regional education boards. However, from around the turn of the present century, this power balance began to be reversed. This process eventually accelerated to such an extent that by the 1970s Ian McLaren aptly described the Department as "a triton among the minnows" (McLaren, 1974, p. 8).

The main focus of this paper is to examine briefly the central-local issue as a factor leading up to the 1989 reforms, and then analyse subsequent developments in the compulsory sector in more detail.

Largely as a reaction against the situation McLaren described, virtually all official committees reviewing as pects of the administration of education for many decades, and particularly in the 20 years prior to the Picot Committee, strongly recommended devolving greater responsibility and authority to the governing bodies of primary and secondary schools, in areas such as finance and appointments, and strengthening parental representation (Barrington, in McKinlay, 1991). Documents produced by these committees included the Nordmeyer (1974) and McCombs (1976) reports, and the 1987 Curriculum Review. A National Advisory Council on Educational Planning report (1975) 
advocated that the Department delegate much of its responsibility for the direct provision of services and detailed control of institutions.

Most initial commentary on the Picot Report and Tomorrow's Schools tended to ignore or overlook the extent to which many of its most central recommendations echoed these earlier recommendations (Nash, 1989; Snook et al., 1989).

A high degree of central control in the existing system was also identified by the Treasury in its 1987 Brief on Education to the Incoming Labour Government, one year prior to the Picot and Tomorrow's Schools reports. Some positive aspects of this were acknowledged by Treasury, including economies of scale in a small country, and the need to ensure uniform and consistent standards. However Treasury also claimed it meant the system could be over-rigid, slow to react to changing demands, lacking in choice and inadequately empowering parent and student users (The Treasury, 1987, p. 10:293).

The central-local issue was raised by Prime Minister Lange at a media briefing on the forthcoming Picot Report in April 1988. He said he was convinced education was over-regulated, but he knew that fundamental to the thinking of the Taskforce was the need to

...marry the difference between an effectivelocal unit of learning and a need to have a central standard or central direction ... I don't accept, and the government couldn't accept, an absolutely autonomous devolution of school management or authority. It's not on and there has been experience in other countries where that has run amok because it's captured by diligent zealots or different religious groups or different educational theorists and it simply can't work. And you also have the problem that you must have in a country like NZ, a certain rock-bottom series of standards which everyone should be able to aspire to. (Lange, 1988)

The Picot Report did emphasize the importance of maintaining local autonomy within national guidelines, a concept commented on at the time by Deputy Prime-Minister Geoffrey Palmer in a discussion on devolution, accountability and education. Palmer interpreted this to mean "plainly enough that the power of the bureaucracy must be devolved to educational institutions themselves, but ... the centre must assume certain critical responsibilities. The centre must set national objectives; it must allocate resources in the way most likely to meet those objectives, and improve standards of performance in the light of those objectives. So, in a sense, it's a partnership between each unit and the centre" (Palmer, in Martin and Harper, 1988, p. 5).

\section{The Tomorrow's Schools Reforms}

Tomorrow's Schools itself embodied a significant move to decentralisation or school-based management, although a distinction needs to be made here between decentralisation (transfer of responsibility) and devolution (transfer of power). Much of the international literature on decentralisation and education describes a process whereby greater responsibility is passed from a central to a sub-regional unit or authority. To abolish the intervening body (education boards) between the central authority and schools altogether as New Zealand did was, at the time it occurred, a radical approach.

The rights and responsibilities of boards of trustees are set out in Section 75 of the Education Act 1989, which provides that, "except to the extent that any enactment or the general law of New Zealand provides otherwise, a school's Board has complete discretion to control the management of the school as it sees fit."

Section 76 outlines the responsibilities of the principal, who (a) "shall comply with the Board's general policy directions"; and (b) "has complete discretion to manage as the principal thinks fit the school's day to day administration."

The ultimate legal responsibility lies with the Board, which has a "wide discretion" (Rae, 1995, p. 65). However it is also clear from the Act that Tomorrow's Schools by no means involved a wholesale devolution of power to boards, and the centre certainly did not abrogate its ultimate authority in a comprehensive range of important areas. Restrictions on devolution to boards are, as mentioned above, embodied in the "otherwise" clause in the Act related to the general law. Section 64 (1) refers to school charters, the details of which must be approved by the Minister, and states that, "Every charter has effect as an undertaking by the Board to the Minister to take all reasonable steps ... to ensure that ... the school is managed, organised, conducted and administered for the purposes set out or deemed to be contained in the charter." Section 60A affirms that the Minister may publish national education goals, curriculum statements and administration guidelines. Section 61(2) sets down that every charter must contain the aims of achieving the national curriculum objectives and guidelines specified by the Minister as core charter elements.

There are legal powers to enforce central restrictions or requirements on boards relating to the maintenance of charters (Education Act 1989, Section 64 (2) (3) and (4)), and also to deal with failure by a board to provide the Audit Office with annual financial 
statements (Section 81B). Where mismanagement, dishonesty, disharmony, incompetence, lack of action or unlawful action is identified, the Minister may dissolve the board (Section 107(a)). The National Opposition signalled in its 1990 Election Manifesto that further changes related to central control and local administration would be forthcoming if the Party was elected. For example, under National, individual schools would be free to re-negotiate their charters and would no longer be "compelled to adhere to Labour's Orwellian social agenda" (p. 4). Almost immediately after the National Party became the Government, the newly-appointed Education Minister, Dr LockwoodSmith, and Associate Minister John Luxton, confirmed in a series of speeches that there would indeed be further curbs on central control:

How can a central agency determine what is best for a school ... the future of central control is now about as bright as that of communism in the Soviet Union. (Associate Minister of Education, PPTA Conference, August 27, 1991)

I have begun to snip at the red tape ... the bureaucracy is under review. (Minister of Education, Educational Administration Conference, March 18, 1991)

Less central control over schools meant there would "clearly be less need for such a large central bureaucracy in education ... over the next two years the central structures will be cut back. (Minister of Education, Principals' Federation, November 21, 1990)

Results were wanted from the classrooms, not the "rooms of the Bureaucrats", and to this end the Minister had asked the Ministry to provide him with a list of "every decision or action for which your schools have to seek approval of the central bureaucracy." (Minister of Education, Education and Training Conference, February 8, 1991)

Our education system despite the supposed devolution of the changes ... remains stultifyingly bound in a web of tangled bureaucracy ... Tomorrow's Schools seems to have been designed by a government determined to keep as much as possible under central control. (Minister of Education, Remuera Rotary Club, February 11, 1991)

Achievement of equality implies centralised decision-making, centralised control of resources, and a welter of regulations, whereas freedom and choice in education implies local decision-making, local control of resources and a minimum of regulation of what parents and schools can and cannot do. (Minister of Education, Conference on Research in Educational Administration, 7 July, 1991)

Treasury also continued to view the Tomorrow's School's reforms as remaining "too heavily reliant on bureaucratic controls" (Brief to the Incoming Government, 1990, p. 133). According to Treasury, the system would be improved by ensuring that central agencies such as the Ministry of Education "do not interpose themselves [on the work of schools locally] beyond ensuring that the minimum requirements of the government as funder are met" (The Treasury, 1990, p. 133).

Speeches by National Ministers, reinforced by Treasury advocacy, turned out to be not just political rhetoric. The centrally funded and administered Parent Advocacy Council was abolished, staff of the Education Review Office (ERO) reduced, and funding to the Special Education Service cut back, leading to the elimination of some speech therapist and visiting teacher positions. The centrally-mandated requirement that anti-sexist and anti-racist clauses be included in school charters was removed, with the Minister saying at the Wanganui Collegiate prize-giving that, "Gone is the politically correct, warm fuzzy liberal social engineering of Marshall, Lange and Goff" (1992). Restructuring and downsizing of the Ministry of Education proceeded virtually from its inception with various functions being shed, decentralised or contracted out (Management Audit, 1996). Included were the Teachers Refresher Course Committee, Learning Media Ltd, the Maori Education Trust, and the teacher exchange function. The Ministry's district office network was reduced from 11 offices to five management centres, consistent with a decrease in operational activity.

The new National Government also quickly introduced legislation to bring about changes at the local level. The 1989 Act was amended to alter the composition of Boards of Trustees. Overall these changes were mainly designed to give boards more flexibility, with implications for parents, students, teachers, and members of the local community in terms of board size, composition, representation and authority (Education Amendment No.4, 1991)

- The previously fixed number of five elected parent representatives could now be varied from not fewer than three to not more than seven parents.

- Parents of pupils could now elect board members who were not themselves parents of pupils. This was intended to meet criticism that confining board membership to parents denied opportunities 
for school boards to utilise people in the community with particular skills that it could benefit from.

- Student representation on boards of secondary schools was changed from compulsory to optional.

- Boards could now approve a body corporate for the purpose of appointing a specified number of trustees to the board, giving them the ability to provide direct representation to bodies such as a PTA or an Old Pupils'Association. This change, as well as that above relating to student representation, represented a return to the pre-1989 situation at the secondary level.

- The power of co-option was also varied: in addition to reflecting the ethnic and socio-economic diversity of the student body (as previously) each board was also now to reflect the "character of the school" and the "character of the community (whether geographical or otherwise) served by the school." In addition, "every board should have available from within its membership expertise and experience in management."

- A restriction was now placed on the election of more employees of a board as trustees a part from the one elected staff representative. This change was undoubtedly intended by its architects to limit what they saw as any undue assertion of teacher power or, as the authors of one Education Review Office publication put it, to protect "the balance between provider and client" (ERO, 1994, p. 6).

Relevant to any discussion of the central and local dimension are the views of those advocating minimal state intervention, or school privatisation, on the extent to which, if at all, government should be involved in education. In Unfinished Business (1993) Roger Douglas claimed Tomorrow's Schools involved only a "Clayton's devolution of power" (p. 86) whereas "central to what I propose lies in removing government as an intermediary between parents and students and educational institutions" (p. 90). Somewhat earlier, the Business Roundtable-commissioned Sexton report (1990) had also argued that decentralization had not gone nearly far enough, but once it had, there "should be little for a Ministry of Education to do, and practically nothing for the other centralised services which were continued or set up under the Education Act 1989" (p. 73). Ideally, Sexton would have the state play no part in education at all, but if it has to it should provide the means only for welfare situations affecting "unfortunate children" (p. 4).

An equally radical critique was made by Dr Byron Lieberman, an American critic of public school systems who was invited to New Zealand by The Centre for Independent Studies in 1993. Publicity for his visit was organised by the same public relations consultant who acted in that capacity for the Business Roundtable, and he put forward a fairly similar view. In his most recent book Public Education: An Autopsy (1993), Lieberman argues that "what has died is the rationale for public education" (p. 1), and a market system utilizing "schools for profit" is preferable to the existing public school system (pp.3, 276-277). American law professor Richard Epstein, invited by the Business Roundtable to give the inaugural Sir Ronald Trotter lecture on the role of the state in education, Wellington, 1995, echoed this view, remarking that "if we were to privatise the entire system we would do far better, and by privatisation I mean no government involvement whatsoever" (p. 34).

The Education Forum, based in Auckland, is an association of people from education and commerce, and its journal The Education Digest frequently contains articles advocating similar or related views. For example, the November, 1994 issue contained an article by Chester Finn, formerly an Assistant Secretary of Education in the Reagan administration, who asked why it was necessary for public education to be administered by government agencies when it could perhaps be better administered if it was " privatised, partly privatised or contracted out" (p. 4). Such views continue to be presented despite the considerable body of historical evidence that points very much the other way. The limited, uneven, and inequitable condition of education in countries like England and New Zealand prior to the development of strong publicly-funded education systems seems a model best left to the 19th century rather than one suitable as we head into the 21st.

\section{The Situation Since 1989}

While there were certainly cut-backs of some central functions, and decentralisation of greater responsibility to boards of trustees certainly occurred, it has already been suggested that it would be quite misleading to describe what has happened as a rush to devolution, in the sense of any wholesale transfer of power from the centre to the local level. Many parents and trustees, whose initial expectations of a greater say over decision-making at the local level had been raised by a skilful public relations campaign, were undoubtedly surprised when they 
realised just how many of the charter requirements, for example, were mandatory and non-discretionary. The National Guidelines, including the major curriculum requirements, can be changed by the Minister at any time without consultation, and further guidelines cover a wide range of matters including personnel, finance, property, enrolment, board meetings and much else. There were aspects of the reforms which represented a very definite increase in central ministerial authority which had not existed previously, one example being the new power given the Minister to remove a board of trustees in certain circumstances. School property management and development provides another example: prior to Tomorrow's Schools it had been decentralised, but was now pulled back into the new Ministry to be controlled by a central property division.

These developments led several commentators to express doubts about how real the professed move to decentralisation really was. Professor Ivan Snook, writing during the initial stage of the reforms, suggested that "the system sold to the electorate as a decentralising measure is becoming more centralised and bureaucratic than before ... The charters, seen originally as giving freedom, are now clearly sources of further control ... The Education Department has re-emerged Phoenix-like to become the Ministry, not with less but with enhanced powers" (Snook, 1989, p. 14). Whereas Picot described school charters as "the lynchpin" of the new system, providing a contract between state, school and community"(p. xi), to Codd and Gordon (1991, p. 21) they came to "signify the power and control of the state." Nash (1989) claimed that putting control of schools in local hands allowed the government to export educational problems downwards whilst retaining control of funding.

Subsequent developments revealed considerable justification for such views. A senior policy analyst at the Ministry of Education described the extent to which in one year (1993) "People at the centre were busy setting up more scrutiny of the local, more frameworks for the local, more ways of finding out what was going on, despite contentions that those closest to the action should make the decisions" (Rae, 1995, p. 67). He identified five centrally driven developments impacting on schools in that year alone, including the New Zealand Curriculum Framework, revised National Education Guidelines, legislation for the Education Review Office, New Zealand Qualifications Authority (NZQA) accreditation procedures, and requirements of the Public Finance Act ( Rae, 1994, pp. 8-18)
Rae also identified various legal devices available to central agencies with regard to curriculum delivery which, "assert national considerations over local interest" (Rae, 1995, p. 67). These include legislation, regulations, gazetted statements, official announcements in the Education Gazette and administrative circulars. He acknowledged that legislation should be used reluctantly to "restrict a creative process" at the local level, but also pointed out that education equips future citizens and uses state funding, therefore any local or short term practices or decisions which might negatively affect individuals' life chances or the competitiveness or viability of the society needed to be prevented. Limiting the discretion available to boards of trustees achieved this. However, as Rae correctly goes on to point out, local trustees themselves have a responsibility to ensure a balance is struck between adhering to national goals and meeting individual and local needs, including acknowledging the place of Maori and the Treaty of Waitangi (Rae, 1995, p. 68).

The significant powers retained by central government and embodied in the Education Act were also identified in a 1996 management audit of the Ministry of Education. These included powers of gate-keeping (control the opening of new schools and early childhood centres); prescription (regulate standards for the content, administration and management of educational delivery); and enforcement (audit the delivery of education) (p. 32).

The law therefore gives the Minister and the Ministry a great deal of power over schools and early childhood centres. For example, the Government can: (1) withdraw license or registration; (2) close schools; (3) dissolve a school board and appoint a commissioner; (4) direct a school to appoint a financial manager (p. 35).

However the State Service Commission's Management Audit (1996), referred to earlier, also identified a need for the Ministry to further enhance its central policy leadership role across the sector to facilitate progress of substantive policy issues. It described the education sector as complex, fragmented and highly politicised, characterised by several central agencies influencing policy directions, demanding central leadership from the Ministry on the one hand, while on the other constraining its ability to exercise such a role. The Ministry's relationship with agencies such as NZQA and ERO was identified as sometimes leaving the Ministry in an ambiguous position, unsure whether or not it had oversight responsibilities for specific policy issues. The audit report also identified a risk that continuing future operational 
responsibilities facing the Ministry might divert its attention and reduce its capacity to tackle broader and more strategic policy issues confronting the sector (pp. 15-16).

Comments with particular relevance for the theme of this paper were made in the report's conclusion:

Like the Duke of York's troops, the Ministry has been marched up to the top of the hill and now appear to be - if not on their way back down again - perhaps nether up nor down. Initially the Ministry was supposed to keep its hands off schools, for fear that the natural instincts of the inspectorate - to interfere with supposedly self-managing schools - would re-emerge and contaminate the "Picot" vision. Now, for reasons variously described as "change management" or "protecting the ownership interest" or "support for schools at risk", the Ministry is redeveloping a role in intervention in schools.

Given these factors, the role of the Government and the Ministry is fraught with ambiguity. Is it intervening to avert failure - with the implicit sanction of the law behind it - or is it offering support and advice which may be freely taken or rejected? What is it trying to achieve by its interventions - minimum compliance with the law or a high standard of performance in schools? (p. 83)

\section{The Current Situation}

The current situation appears characterised by intermittent tension, whereby the Government seeks to devolve in a particular area, finds there are difficulties, and so reasserts a central oversight. One example of this is the scheme announced by the Coalition Government as one of its key policy objectives in education, to ease the administrative burden which the reforms imposed, particularly on principals and trustees in smaller schools (Coalition Agreement: Education, 1996). This scheme will provide $\$ 5.8$ million over three years to encourage the boards of smaller schools to work together in clusters, assisted by facilitators contracted by the Ministry of Education, to arrange joint purchasing and collective access to financial, personnel and property management expertise.

Another example relates to equity, a hardy perennial in the central-local domain, which has already been touched on several times in this paper. Codd (1993) noted a tension in the New Zealand reforms between the market liberal and social justice concepts of education. To take just one example of this, on the one hand there are national curriculum statements to establish nation-wide common goals and opprtunities for all schools and students; on the other, the abolition of zoning was designed to promote choice and allow competition between schools.

In recent times, dissatisfaction has developed in some communities, arising from the 1991 school zoning decision, at the extent to which some schools have developed enrolment schemes in such a way that students living in the immediate neighbourhood of the school have been denied entry whereas more distant students whom schools favour have been admitted. Then the centre is forced to act once more to reassert its authority through legislative means. The Coalition Agreement on education now has as a key policy initiative within the term of the current parliament "to support the concept that priority for attendance at neighbourhood schools will be given to those living in the local area "(Codd, 1996).

The Association representing school trustees is adamant that "we don't want any central control body brought back in.... The concept of self-management is good ....The community has been given greater control of our schools and that is the way it should be" (Janet Kelly, President New Zealand School Trustees Association, as reported in the Evening Post, 31 October, 1996). Certainly at the school level there has undoubtedly been a significant change in the way the centre is viewed. Whereas the former Department always seemed to to be looking out towards schools, the Ministry of Education looks towards the Minister. This inevitably also changes the central/Minister relationship with schools. The most recent report from the New Zealand Council for Educational Research dealing with the issue (Wylie, 1997) revealed scope for improvement in the relationship between schools and the Ministry. Although the quality of relationships between principals and trustees at the school level was described as at least "good" by around 80 percent of them, only about half the principals described relationships between the school and the Ministry as "good" or better.

\section{Conclusion}

The central-local issue remains a perennial one in New Zealand education, although now in somewhat different terms. Prior to the Picot Taskforce, most reforming reports focussed on, and to some extent were mesmerised by, questions of the constitution, functions and powers of regional educational authorities. Picot, in marked contrast, quickly and decisively decided against having any such authorities at all. The recent 
modest innovation designed to ease the burdens of principals and trustees has already been referred to, and it will be interesting to see whether any further central involvement of this kind becomes necessary. But any return to an "education board" model as an intermediate administrative unit between the centre and local area now seems virtually unthinkable. The new players on centre stage are the advocates of privatisation, who would like all debate on central-local control to cease, and a central state-provided and state-controlled system to be either severely reduced or eliminated altogether.

Changes to educational administration since 1989 have been characterised more by decentralisation than devolution, with many crucial powers retained at the centre and greater responsibility, rather than greater power, being given to schools. This phenomenon needs to be seen in a wider international context (Chapman, 1991). To the extent that parallel developments have often occurred, with increases in central authority being matched simultaneously by greater decisionmaking responsibilities at the local level, terms like "centralisation" and "decentralisation" seem rather inadequate to describe with complete accuracy the nature of the metamorphosis which has occurred in our school system.

\section{References}

Advisory Council on Educational Planning. (1975). Directions for educational development. Wellington: Government Printer.

Barrington, J. M. (1990). Historical factors for change in education. In P. Mckinlay, Redistribution of power? - Devolution in New Zealand. Wellington: Victoria University Press, for the Institute of Policy Studies.

Chapman, J. (1991). The effectiveness of schooling and of educational resource management. Paris: OECD.

Coalition Agreement. (1996). Key policy initiatives in education. Wellington: Coalition Agreement.

Codd, J. (1993). Equity and choice: The paradox of New Zealand education reform. Curriculum Studies, 1(1) 75-90.

Codd, J., \& Gordon, L. (1991). School charters: The contractualist state and education policy. New Zealand Journal of Educational Studies, 26(1), 21-34.

Douglas, R. (1993). Unfinished business. Auckland: Random House.

Epstein, R. A. (1995). The role of the state in education. The Sir Ronald Trotter lecture. Wellington: New Zealand Business Roundtable.
Education Review Office. (1994). Effective Governance, No. 7. Wellington: ERO.

Finn, C. (1995, August). What to do about education. Education Digest.

Husén, T., \& Postlethwaite, T. (1985). The international encyclopedia of education. New York: Pergamon.

Government of New Zealand. (1989). An Act to Reform the Administration of Education. No. 80.

Government of New Zealand. (1991). Education Amendment (No. 4). Act to Amend the Education Act, 1989.

Kelly, J. (1996, October 10), Evening Post.

Lieberman, M. (1993). Public education: An autopsy. Cambridge, Mass: Harvard University Press.

McLaren, I. A. (1974). Education in a small democracy: New Zealand. London: Routledge and Kegan Paul.

Nash, R. (1989). Tomorrow's Schools: State power and parent participation. New Zealand Journal of Educational Studies, 24(2), 113138.

New Zealand National Party. (1990). Election Manifesto.

Office of the Minister of Education. (1988). Tomorrow's Schools. Wellington: Government Printer.

Office of the Minister of Education. (1988, April). Media briefing.

Office of the Minister and Associate Minister of Education. (1991). Addresses.

Palmer, G. (1988). Political perspectives. In J. Martin \& J. Harper, Devolution and accountability. Wellington: New Zealand Institute of Public Administration.

Rae, K. (1994). New Zealand self-managing schools and five impacts in 1993 from the ongoing restructuring of educational administration. Paper to NZEAS Conference. Auckland, January 16-19.

Rae, K. (1995, December). Issues of quality curriculum delivery - A perspective from the centre. New Zealand Journal of Educational Administration, 10, 65-71.

Report of the Working Party on Organisation and Administration. (1974). Organisation and administration (Nordmeyer report). Wellington: Government Printer.

Report of the Committee on Secondary Education. (1976). Towards partnership (McCombs Report). Wellington: Government Printer.

Report of the Taskforce to Review Education Administration. (1988). Administering for excellence (Picot Report). Wellington Government Printer. 
Sexton, S. (1990). New Zealand schools. Wellington: New Zealand Business Roundtable.

Snook, I. (1989). Educational reform in New Zealand: What is going on? Access, 8(2), 9-18.

State Services Commission. (1996). Ministry of Education management audit. Wellington: SSC

The Treasury. (1987). Government management - Brief to the incoming government. Vol. 2. Education issues. Wellington: Government Printing Office.

The Treasury. (1990). Brief to the incoming government (Education). Wellington: Government Printing Office.

Webb, L. (1937). The control of education in New Zealand. Wellington: New Zealand Council for Educational Research.

Weiler, H. N. (1990). Comparative perspectives on educational decentralization: An exercise in contradiction? Educational Evaluation and Policy Analysis, 12(4), 439-446.

Wylie, C. (1997). Self-managing schools seven years on: What have we learnt? Wellington: New Zealand Council for Educational Research.

\section{The author}

Dr John Barrington is Associate Professor in the School of Education at Victoria University of Wellington. His current research interests focus on New Zealand educational policy administration and history. 